\title{
Kelayakan rencana bisnis komoditas kesatuan pengelolaan hutan produksi (KPHP) DAS Belayan Provinsi Kalimantan Timur
}

\author{
Rahmadi; Sahrul Uma; Elsy Riawati; Muhammad Ridwansyah* \\ UPTD Kesatuan Pengelolaan Hutan Produksi DAS Belayan, Dinas Kehutanan \\ Provinsi Kalimantan Timur \\ *E-mail korespondensi: mridwansyahjbi@gmail.com
}

\begin{abstract}
Abstrak
KPHP Unit XXVI Belayan Watershed has a management area for production forest and protected forest that has not been optimally utilized. This study aims to develop a business plan strategy in order to optimize the resources of the KPHP Belayan watershed which is oriented towards reducing emissions to achieve sustainable forest management, improving people's welfare, and increasing income. This study use SWOT analysis to determine the right strategy in order to optimize the resources of the KPHP Belayan Watershed. The analysis results show that the commodity business (palm sugar, palm solid sugar, forest honey and kelulut honey, bamboo skewers and carbon trading) by the KPHP Belayan Watershed is financially feasible to be financed. This means that the strategy that must be carried out is to expand the market segmentation of these commodities so that these commodities can advance.
\end{abstract}

Keywords: Belayan watershed, Production forest, Sustainable forest, SWOT

\begin{abstract}
Abstrak
KPHP Unit XXVI DAS Belayan memiliki wilayah kelola kawasan hutan produksi dan hutang lindung yang belum dimanfaatkan secara optimal. Penelitian ini bertujuan untuk menyusun strategi perencanaan bisnis (business plan strategy) dalam rangka mengoptimalkan sumber daya KPHP DAS Belayan yang berorientasi pada pengurangan emisi untuk mencapai pengelolaan hutan lestari, meningkatkan kesejahteraan rakyat, dan meningkatkan pendapatan. Penelitian ini menggunakan analisis SWOT untuk menentukan strategi yang tepat guna mengoptimalkan sumber daya di KPHP DAS Belayan. Hasil analisis menunjukkan bahwa komoditas usaha (gula aren, gula padat aren, madu hutan dan madu kelulut, tusuk bambu dan perdagangan karbon) oleh KPHP DAS Belayan secara finansial layak untuk dibiayai. Artinya strategi yang harus dilakukan adalah dengan memperluas segmentasi pasar komoditas - komoditas tersebut sehingga komoditas - komoditas ini dapat maju.
\end{abstract}

Kata kunci: DAS Belayan, Hutan produksi, Hutan sustainable, SWOT

\section{PENDAHULUAN}

Berdasarkan RPHJP KPHK DAS Belayan (2018), KPHP Unit XXVI DAS Belayan sesuai Surat Keputusan Menteri Lingkungan Hidup dan Kehutanan Republik Indonesia Nomor: SK. 290/MENLHK-KPHP/PKPHP/HPL.0/2/2018 tanggal 2 Februari 2018. 
KPHP Unit XXVI DAS Belayan memiliki wilayah kelola luas seluas 998.199,49 hektar yang terbagi dalam beberapa blok pengelolan adalah sebagai berikut adalah Blok Pemanfaatan HHA-HA dan Blok Pemanfaatan HHK-HT seluas 684.071,79 Ha (68,53\%), Blok inti seluas 94,786,60 Ha (9,50\%), Blok Pemanfaatan seluas 112.961,92 Ha $(11,32 \%)$, Blok Pemanfaatan HHBK-Jasling seluas 43.408,17 Ha $(4,35 \%)$ dan Blok Pemberdayaan Masyarakat seluas 62.971,01 Ha (6,30\%).

Dalam Wilayah KPHP Unit XXVI DAS Belayan terdapat pula Kawasan Hutan yang belum di bebani Hak/izin Pemanfaatan atau penggunaan kawasan kawasan atau wilayah tertentu (WT) seluas 272.566,28 hektar dan non wilayah tertentu (non WT) seluas 725.633,19 hektar yaitu kondisi umum KPH Wilayah KPHP Unit XXVI DAS Belayan sebagian besar merupakan Kawasan Hutan Produksi Terbatas (HPT) dan Kawasan Hutan Lindung (HL) sehingga sebagian besar wilayah memiliki aksesibilitas rendah maka sebagian besar masih merupakan areal hutan primer, diikuti sekunder bekas tebangan (logged-over areas) dan juga semak belukar bekas perladangan masyarakat (terutama di sekitar pemukiman penduduk), ringkasan potensi sumber daya yang ada, perlunya pengelolaan sumber daya hutan yang efisien dan akuntabel menuju KPH Mandiri (Dinas Kehutanan, 2018).

Beberapa tugas utama dari KPHP DAS Belayan adalah menyelenggarakan kegiatan pengelolaan hutan secara lestari melalui: Pemanfaatan hasil hutan bukan kayu (HHBK), Pengembangan wisata Jasa Lingkungan dan ekowisata, pemberdayaan masyarakat melalui Perhutanan Sosial, pendampingan program Hutan Kemasyarakatn (HKm) serta program Kemitraan dengan Kelompok Tani Hutan.

Adapun tujuan dari penelitian ini adalah untuk mengurangi aktifitas ilegal di dalam kawasan hutan (perambahan), melihat peluang adanya mata pencaharian baru, meningkatnya penghasilan masyarakat melalui pengembangan produk yang berasal dari hasil hutan bukan kayu di sekitar KPHP DAS Belayan yang berorientasi pada pengurangan emisi untuk mencapai pengelolaan hutan lestari, meningkatkan kesejahteraan rakyat, dan meningkatkan pendapatan. Untuk itu diperlukan adanya Perencanaan Bisnis KPHP yang berorientasi pada pengurangan emisi untuk mencapai pengelolaan hutan lestari, meningkatkan kesejahteraan rakyat, dan meningkatkan pendapatan.

Prioritas kegiatan pada pemanfaatan hutan pada wilayah tertentu di dalam wilayah KPHP Sub DAS Belayan direncanakan pada pengembangan 3 (tiga) core businesses di blok-blok yang telah ditentukan. Pengembangan usaha tersebut adalah sebagai berikut: 1).Pengelolaan dan pengembangan hutan tanaman, 2).Pengelolaan dan pengembangan HHBK, seperti: penyedia sumber benih, rumput ketak/mintu, tumbuhan obat, damar, lebah madu, air mineral, aren, gaharu dan lain-lain; 3).Pengelolaan jasa lingkungan untuk penyerapan karbon.

GIZ (2017) menjelaskan bahwa Business Plan atau Rencana Bisnis merupakan salah satu dokumen penting baik bagi pelaku usaha (baik individu maupun perusahaan) yang dapat dijadikan acuan dalam aktivitas bisnisnya guna mencapai tujuan bisnis yang diinginkan. Selain bermanfaat sebagai pegangan atau acuan dalam menjalankan bisnis (internal) rencana bisnis juga akan sangat bermanfaat bagi pihak lain (eksternal) seperti: pemilik perusahaan, investor, pemilik modal, pemerintah, masyarakat, dan pihak lain yang terkait dengan aktivitas bisnis bersangkutan.

Menurut Ridwansyah (2018) Berdasarkan fungsi, produk/jasa komoditas yang dikembangkan oleh pihak KPH, termasuk ke dalam kategori produk konsumsi, yaitu produk/jasa yang dibeli dan digunakan oleh konsumen akhir (pemakai akhir) yang memiliki prinsip meliputi: 1).Convenience goods, yaitu produk yang dibutuhkan sehari- 
hari dan mudah didapat, misalnya beras, gula, teh, permen, dll. 2).Shopping goods, yaitu produk-produk yang dibedakan oleh konsumen berdasarkan kualitas, harga, tren, dan gaya. Contohnya adalah bahan untuk diet, oleh-oleh, dsb. 3).Specialty goods, yaitu produk yang mempunyai karakteristik unik dan mempunyai merek yang sudah terkenal; misalnya beras premium, lobster, kepiting dsb. 4).Unsought goods, adalah produk yang kurang dikenal atau diketahui umum tetapi kurang diminati, misalnya hasil hutan bukan kayu: gadung. 5).Jika termasuk produk industri, yaitu produk yang biasa dibeli oleh pelaku usaha produksi lainnya. Biasa dikenal dalam B to B (business to business). Dapat dibagi dalam 3 golongan, yaitu: a).Bahan baku dan suku cadang: merupakan bahan mentah yang akan diproses lebih lanjut. b).Barang modal: yaitu barang-barang yang berumur lebih dari 1 tahun dan tidak untuk dijual belikan. c).Perlengkapan dan jasa bisnis, yaitu produk tidak tahan lama yang membantu operasional perusahaan.

Manfaat yang dapat ditawarkan oleh komoditas/produk/jasa oleh KPHP DAS Belayan dapat dibagi dalam 5 tingkatan, antara lain: 1).Manfaat inti (core benefit): adalah manfaat yang diberikan untuk pemenuhan terhadap kebutuhan pokok. 2).Manfaat dasar (basic benefit): adalah manfaat dasar yang diberikan untuk memecahkan masalah kebutuhan utama, 3).Manfaat yang diharapkan (expected benefit): adalah manfaat yang diharapkan lebih dari sekedar pemenuhan kebutuhan pokok, 4).Manfaat di atas harapan (augmented benefit): adalah manfaat yang dapat diberikan lebih dari yang diharapkan oleh konsumen. 5).Manfaat potensial (potential benefit): adalah semua manfaat yang mungkin dapat diberikan lebih dari sekedar augmented benefit

Nilai manfaat produk/jasa/komoditas yang ditawarkan tersebut cendrung memiliki manfaat dasar dan manfaat potensial bagi calon konsumen. Untuk keperluan estimasi nilai hasil hutan non kayu, menarik untuk menyimak studi yang dilakukan oleh Chopra (1993) di hutan tropika di India. Dalam penelitiannya, Chopra mengetengahkan analisa finansial biaya-manfaat hutan non kayu terhadap hutan tropis basah dan hutan tropis kering dari hutan sekunder berdasarkan nilai total ekonomi. Analisa meliputi nilai manfaat langsung dan tak langsung, nilai pilihan dan nilai keberadaan. Suku bunga yang digunakan adalah $12 \%$ selama 30 tahun waktu perencanaan, digunakan untuk menghitung net present value (NPV). Metode valuasi yang digunakan adalah teknik pasar dan non-pasar (market and non market based techniques). Hasil studi ini menunjukkan bahwa jumlah nilai guna langsung dan tak langsung dari hutan yang diestimasi diperkirakan antara US\$220 dan \$ 357 per ha per tahun.

Howard (1995) melakukan analisa finansial dan ekonomi terhadap pengelolaan kawasan lindung. Data yang digunakan meliputi nilai pasar dari informasi penerimaan konsesi kawasan lindung dan penerimaan di lokasi, biaya masuk, penerimaan dari usaha hutan tanaman dan penerimaan lain dari lisensi barang-barang konsumsi seperti: kayu, arang, dan manau. Adapun jasa lingkungan yang tidak memiliki nilai pasar (nonmarketted items) dinilai berdasarkan informasi yang dikumpulkan dari survei terhadap 84 rumah tangga di enam desa. Produk hutan nonkayu yang dinilai meliputi: kayu bakar, manau, kayu, arang, atap ilalang, daging, pangan dan air.

\section{METODE}

Analisis investasi digunakan untuk mengukur nilai uang atau tingkat pengembalian dari investasi yang ditanamkan dalam suatu usaha pada masa yang akan datang. Hal ini sangat penting dilakukan sebelum implementasi investasi yang sering mempertaruhkan dana yang sangat besar. Dengan melakukan berbagai macam simulasi tersebut, akan diketahui besarnya faktor-faktor resiko yang akan dihadapi, dan yang mempengaruhi layak atau tidaknya suatu rencana investasi. Beberapa metode analisa yang dapat 
dipergunakan adalah :

Metode non-discounted cash flow

Non-Discounted Cash Flow adalah metode pengukuran investasi dengan melihat kekuatan pengembalian modal tanpa mempertimbangkan nilai waktu terhadap uang (time value of money). Metode yang dipergunakan adalah Pay Back Period (PBP) Method, dengan formula umum sbb:

$$
\begin{aligned}
& \text { Total Investasi } \\
& \text { Pay Back Period = ----------------------- x } 1 \text { tahun }
\end{aligned}
$$

Metode PBP merupakan alat ukur yang sangat sederhana, mudah dimengerti dan berfungsi sebagai tahapan paling awal bagi penilaian suatu investasi. Model ini umum digunakan untuk pemilihan alter-natif-alternatif usaha yang mempunyai resiko tinggi, karena modal yang telah ditanamkan harus segera dapat diterima kembali secepat mungkin. Kelemahan utama dari metode PBP ini adalah: 1).Tidak dapat menganalisa penghasilan usaha setelah modal kembali. 2).Tidak mempertimbangkan nilai waktu uang

\section{Metode discounted cash flow}

Yakni metode pengukuran investasi dengan melihat nilai waktu uang (time value of money) dalam menghitung tingkat pengembalian modal pada masa yang akan datang. Analisa ini penting dilakukan sebelum implementasi investasi yang sering mempertaruhkan dana yang sangat besar. Dengan melakukan berbagai macam simulasi tersebut, akan diketahui besarnya faktor-faktor resiko yang akan dihadapi, dan yang mempengaruhi layak atau tidaknya suatu rencana investasi.

\section{Net present value (NPV)}

NPV didefinisikan sebagai selisih antara investasi sekarang dengan nilai sekarang (present value) dari proyeksi hasil-hasil bersih masa datang yang diharapkan. Dengan demikian, NPV dapat dirumuskan:

NPV $=$ PV of Benefit - PV of Capital Cost atau karena PV $=\left(C /(1+\mathrm{i})^{\mathrm{n}}\right)$, maka:

$$
\mathrm{NPV}=\sum \frac{\mathrm{C}}{(1+\mathrm{i})^{\mathrm{n}}}+\sum \frac{-\mathrm{C}}{(1+\mathrm{i})^{\mathrm{n}}}
$$

Dimana: $\quad$ i $\quad=$ Bunga tiap periode

$$
\begin{array}{ll}
\mathrm{N} & =\text { Periode (tahun, bulan) } \\
-\mathrm{C} & =\text { Modal (capital) } \\
\mathrm{C} & =\text { Hasil bersih } \text { (proceed })
\end{array}
$$

Kriteria yang dipergunakan dalam penilaian NPV adalah sbb: 1).Jika NPV $=0$ (nol), maka hasil investasi (return) usaha akan sama dengan tingkat bunga yang dipakai dalam analisis, atau dengan kata lain usaha tidak untung maupun rugi (impas). 2).Jika NPV = (negatif), maka investasi tersebut rugi atau hasilnya (return) di bawah tingkat bunga yang dipakai. 3).Jika NPV $=+$ (positif), maka investasi tersebut mengun-tungkan atau hasilnya (return) melebihi tingkat bunga yang dipakai.

Kelemahan utama dari metode NPV ini adalah bahwa ia tidak menganalisis pemilihan alternatif usaha-usaha dengan jumlah investasi yang berbeda. 


\section{Internal rate of return (IRR)}

Internal Rate of Return didefinisikan sebagai besarnya suku bunga yang menyamakan nilai sekarang (present value) dari investasi de-ngan hasil-hasil bersih yang diharapkan selama usaha berjalan. Patokan yang dipakai sebagai acuan baik tidaknya IRR biasanya adalah suku bunga pinjaman bank yang sedang berlaku, atau suku bunga deposito jika usaha tersebut dibiayai sendiri. Perhitungan IRR secara manual cukup kompleks, karena harus menggunakan beberapa kali simulasi atau melakukan pola try and error. Namun demikian, untuk skenario dua nilai NPV yang telah diketahui sebelumnya, IRR dapat dirumuskan sebagai:

$$
\begin{array}{cc}
\mathrm{NPR}_{1}=\mathrm{i}_{1}+\left(\mathrm{i}_{2}-\mathrm{i}_{1}\right) \mathrm{x} & \left(\mathrm{NPV}_{1}-\mathrm{NPV}_{2}\right)
\end{array}
$$

Dimana: $\quad \mathrm{NPV}_{1}$ harus di atas $0\left(\mathrm{NPV}_{1}>0\right)$

$\mathrm{NPV}_{2}$ harus di bawah $0\left(\mathrm{NPV}_{2}<0\right)$

\section{HASIL DAN PEMBAHASAN \\ Dimensi komoditas/produk/jasa}

Dimensi komoditas/produk/jasa yang menjadi rencana usaha komoditas KPHP DAS Belayan dengan sifat, ciri-ciri komoditas dan fungsinya sebagai berikut:

Tabel 2. Ciri-ciri komoditas dan fungsi.

\begin{tabular}{|c|c|c|c|c|c|}
\hline No & Komoditas & $\begin{array}{l}\text { Deskripsi Umum } \\
\text { Produk }\end{array}$ & Sumber Bahan & $\begin{array}{l}\text { Ukuran } \\
\text { Kemasan }\end{array}$ & Ket \\
\hline 1. & $\begin{array}{l}\text { Gula Aren } \\
\text { Batangan }\end{array}$ & $\begin{array}{l}\text { Barang konsumsi } \\
\text { rumah tangga } \\
\text { sehari-hari }\end{array}$ & $\begin{array}{l}\text { Nira Aren dari Kebun aren } \\
\text { masyarakat }\end{array}$ & $\begin{array}{l}250 \mathrm{gr} \mathrm{s} / \mathrm{d} \\
1.000 \mathrm{gr} \text { dengan } \\
\text { kemasan sesuai } \\
\text { ukuran }\end{array}$ & $\begin{array}{l}\text { Bentuk bulat dan } \\
\text { batangan }\end{array}$ \\
\hline 2. & $\begin{array}{l}\text { Gula semut } \\
\text { Aren }\end{array}$ & $\begin{array}{l}\text { Barang konsumsi } \\
\text { sehari-hari hasil } \\
\text { pengolahan nira } \\
\text { aren }\end{array}$ & $\begin{array}{l}\text { Nira Aren dari Kebun aren } \\
\text { masyarakat }\end{array}$ & $\begin{array}{l}25 \mathrm{gr} \\
\text { s/d } 100 \text { gr dengan } \\
\text { kemasan } \\
\text { plastik/kertas } \\
\text { sesuai ukuran }\end{array}$ & $\begin{array}{l}\text { Dikonsumsi dapat } \\
\text { bentuk butiran } \\
\text { atau pun kubus } \\
\text { padatan }\end{array}$ \\
\hline 3. & $\begin{array}{l}\text { Tusuk sate } \\
\text { bambu }\end{array}$ & $\begin{array}{l}\text { Barang pelengkap } \\
\text { konsumsi sehari- } \\
\text { hari }\end{array}$ & $\begin{array}{l}\text { Bambu yang berasal dari } \\
\text { Kebun masyarakat }\end{array}$ & $\begin{array}{l}\text { Kemasan } 250 \\
\text { gram Ukuran stik } \\
\text { panjang } 10-25 \\
\text { cm, kemasan } \\
\text { plastik }\end{array}$ & $\begin{array}{l}\text { Bentuk Tusuk } \\
\text { panjang dan } \\
\text { Pendek }\end{array}$ \\
\hline 4. & Madu Alam & $\begin{array}{l}\text { Madu yang berasal } \\
\text { dari Hutan di } \\
\text { wilayah KPHP Sub } \\
\text { DAS Belayan yang } \\
\text { dikumpulkan oleh } \\
\text { pengumpul madu }\end{array}$ & Madu Alam & $\begin{array}{l}\text { Botol platik } \\
\text { ukuran } 100 \\
\mathrm{ml} / 250 \mathrm{ml}\end{array}$ & $\begin{array}{l}\text { Minuman } \\
\text { kesehatan }\end{array}$ \\
\hline 5. & $\begin{array}{l}\text { Madu } \\
\text { Kelulut }\end{array}$ & $\begin{array}{l}\text { Madu yang berasal } \\
\text { dari Ternak di } \\
\text { wilayah sekitar } \\
\text { KPHP Sub DAS } \\
\text { Belayan oleh } \\
\text { kelompok tani } \\
\text { hutan }\end{array}$ & $\begin{array}{l}\text { Ternak madu kelulut/apis } \\
\text { cerana (madu lokal) }\end{array}$ & $\begin{array}{l}\text { Botol platik } \\
\text { ukuran } 100 \mathrm{ml} \mathrm{s} / \mathrm{d} \\
250 \mathrm{ml}\end{array}$ & $\begin{array}{l}\text { Minuman } \\
\text { kesehatan }\end{array}$ \\
\hline 6. & $\begin{array}{l}\text { Carbon } \\
\text { stock dan } \\
\text { trade off }\end{array}$ & $\begin{array}{l}\text { Berupa jasa } \\
\text { menjasa lingkungan }\end{array}$ & $\begin{array}{l}\text { Areal wilayah tertentu } \\
\text { yang memiliki karbon } \\
\text { stock yang rentan } \\
\text { degaradasi dan deforestasi }\end{array}$ & $\begin{array}{l}108,266.50 \\
\text { Ton/ha }\end{array}$ & $\begin{array}{l}\text { Berupa kegiatan } \\
\text { pengelolaan yang } \\
\text { berkaitan dengan } \\
\text { konservasi carbon }\end{array}$ \\
\hline
\end{tabular}




\section{Kapasitas produksi}

Perencanaan kapasitas produksi dilakukan untuk semua lahan, peralatan, dan faktor produksi lainnya sesuai dengan rencana jumlah komoditas/produk akhir yang akan dihasilkan. Kapasitas produksi disusun dengan tingkatan yang rinci dengan mengacu pada hasil dari perhitungan peluang pasar atas produk yang bersangkutan. Proyeksi kapasitas produksi dilakukan dalam jangka minimal 3 tahun ke depan, sesuai dengan rencana produksinya:

Tabel 3. Proyeksi kapasitas produksi.

\begin{tabular}{clcc}
\hline No & \multicolumn{1}{c}{ Komoditas } & Target produksi & $\begin{array}{c}\text { Jangka Waktu } \\
\text { Produksi }\end{array}$ \\
\hline 1 & Gula Aren Batangan & 5 Ton / Tahun & 10 Tahun \\
& & & \\
2 & Gula semut Aren & 5 Ton / Tahun & 10 Tahun \\
3 & Tusuk sate bambu & 5 Ton / Tahun & 10 Tahun \\
4 & Madu Alam & 2.500 / Tahun & 10 Tahun \\
5 & Madu Kelulut & 2.500 / Tahun & 10 Tahun \\
6 & Carbon stock dan & 80.643,26 Ha sebanding dengan & 10 Tahun \\
& trade off & 108.266 .50 ton CO $^{2}$ & \\
\hline
\end{tabular}

Sumber: Data diolah,

\section{Operasional}

Manpower (tenaga kerja)

Tenaga kerja yang diperlukan berasal dari Kelompok Kerja/Kelompok Tani Hutan di Wilayah KPHP Sub DAS Belayan untuk tenaga lapangan sebanyak 100 orang. Sedangkan perekrutan karyawan kantor diutamakan warga Kaltim meliputi Ketua 1 orang, Sekretaris \& Administrasi Kantor 1 orang, Staff Admin 1 orang, Ka. Humas \& Marketing 1 orang, Staff Marketing 2 orang, Bendahara 1 orang, Staff Keuangan 1 orang, Pengurus Teknologi Komputer 3 orang, dan Office Boy 1 orang dan disesuaikan dengan kondisi produksi selanjutnya.

\section{Materials (bahan)}

Bahan material sumber bahan baku berasal desa disekitar KPHP Das Belayan yang banyak tesedia baik yang ada diluar kawasan hutan maupun di dalam kawasan hutan, namun sampai dengan saat ini belum dapatkan angka pasti potensi HHBK Bambu, Aren dan Madu terhadap areal tersebut.

\section{Machinery (peralatan)}

Peralatan yang diperlukan merupakan peralatan yang termasuk dalam sarana dalam proses produksi berupa permesinan dan rumah kerja dan peralatan pendukung sarana produksi seperti mobil angkutan dan sebagainya yang berasal dari hibah, pembiayaan dan, dimana pada saat ini yang masih dapat.

\section{Organisasi \& Management (manajemen)}

Bimbingan kelembagaan terhadap kelompok tani/kelompok kerja/kelompok binaan, Pemberdayaan dan manajerial tetap dilakukan oleh pihak KPHP DAS Belayan. 


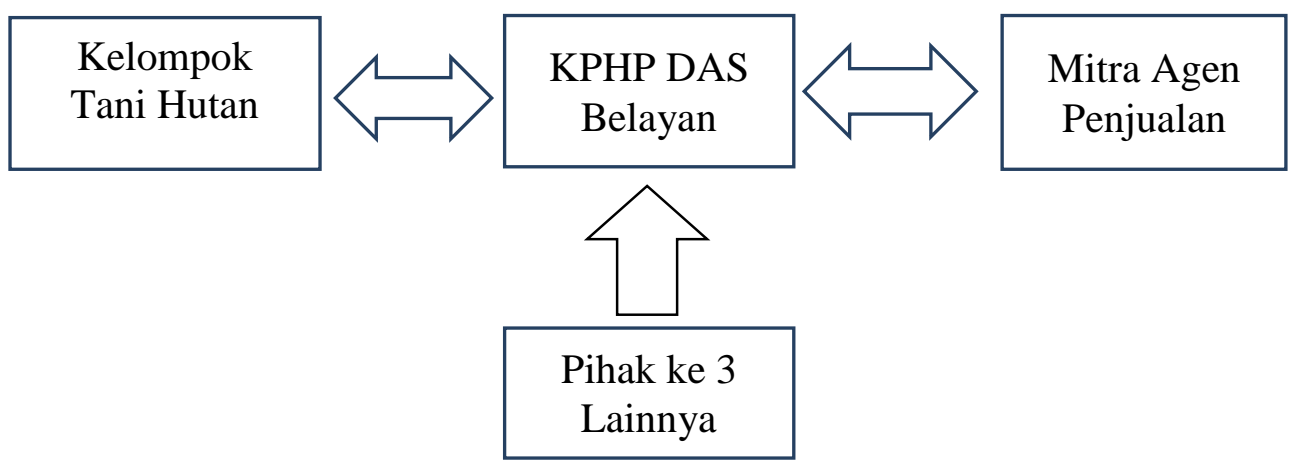

Gambar 2. Bagan operasional

\section{Pemasaran}

Keadaan permintaan pasar madu yang merupakan permintaan berdasarkan keinginan terhadap produk kesehatan berupa madu yang didukung oleh daya beli masyarakat. Segmen Pasar, merupakan gambaran umum dari konsumen usaha. Target Pasar, merupakan sasaran khusus bagi konsumen potensial dari usaha. Positioning, adalah bagaimana menempatkan usaha yang akan dikembangkan diantara pesaing usaha yang sejenis.

Tabel 4. Pemasaran.

\begin{tabular}{|c|c|c|c|}
\hline No & Komoditas & Segmen Pasar & Target Pasar \\
\hline 1 & Gula Aren Batangan & $\begin{array}{l}\text { Rumah tangga, } \\
\text { kuliner, dll }\end{array}$ & $\begin{array}{l}\text { pasar moderen dan } \\
\text { Trandisional, Penjualan } \\
\text { Online }\end{array}$ \\
\hline 2 & Gula semut Aren & $\begin{array}{l}\text { Rumah tangga, } \\
\text { kuliner, dll }\end{array}$ & $\begin{array}{l}\text { pasar moderen dan } \\
\text { Trandisional, Penjualan } \\
\text { Online }\end{array}$ \\
\hline 3 & Tusuk sate bambu & $\begin{array}{l}\text { Rumah tangga, } \\
\text { kuliner, dll }\end{array}$ & $\begin{array}{l}\text { pasar moderen dan } \\
\text { Trandisional, Penjualan } \\
\text { Online }\end{array}$ \\
\hline 4 & Madu Alam & $\begin{array}{l}\text { Toko Jamu, Obat- } \\
\text { obatan }\end{array}$ & $\begin{array}{l}\text { pasar moderen dan } \\
\text { Trandisional, Penjualan } \\
\text { Online }\end{array}$ \\
\hline 5 & Madu Kelulut & $\begin{array}{l}\text { Toko Jamu, Obat- } \\
\text { obatan }\end{array}$ & $\begin{array}{l}\text { pasar moderen dan } \\
\text { Trandisional, Penjualan } \\
\text { Online }\end{array}$ \\
\hline 6 & $\begin{array}{l}\text { Carbon stock dan } \\
\text { trade off }\end{array}$ & Bank Dunia & $\begin{array}{l}\text { pasar moderen dan } \\
\text { Trandisional, Penjualan } \\
\text { Online }\end{array}$ \\
\hline
\end{tabular}

\section{Proyeksi keuangan}

Proyeksi keuangan merupakan hal paling mendasar dari proposal bisnis (Gula semut aren, gula padat aren, madu hutan dan madu kelulut, tusuk sate bambu dan perdagangan karbon) dimana hal tersebut dapat memperlihatkan potensi dana yang dimiliki, kebutuhan dana eksternal, perhitungan kelayakan usaha, termasuk di dalamnya 3 performa laporan keuangan: neraca, rugi-laba, dan cash flow.

Secara ringkas, dapat diberikan format sederhana perhitungan kelayakan usaha secara finansial sebagai berikut: 
Sumber pendanaan

Sumber pendanaan berasal dari: Donor Pihak Ke Tiga yang bersifat resmi, APBN/APBD sesuai dengan kemampuan keuangan KPH

\section{Modal investasi}

Modal investasi (Gula semut aren, gula padat aren, madu hutan dan madu kelulut, tusuk sate bambu dan perdagangan karbon) secara keseluruhan adalah Rp. 1.771.820.000,-

\section{Biaya tetap}

Biaya Tetap (Gula semut aren, gula padat aren, madu hutan dan madu kelulut, tusuk sate bambu dan perdagangan karbon) secara keseluruhan adalah Rp.

551.700.000,-

\section{Biaya tidak tetap}

Biaya Tidak Tetap (Gula semut aren, gula padat aren, madu hutan dan madu kelulut, tusuk sate bambu dan perdagangan karbon) secara keseluruhan adalah Rp.1.220.120.000,-

Analisis aliran kas

Arus kas laba dan rugi produk/jasa (Gula semut aren, gula padat aren, madu hutan dan madu kelulut, tusuk sate bambu dan perdagangan karbon) dimulai dari tahun ke-1 sampai dengan tahun ke-10, setelah dilakukan perhitungan menunjukkan hasil pendapatan netto yang positif mulai dari tahun ke-1 dan cash flow yang positif mulai pada tahun ke-2 sampai dengan ke- 10. Hal ini dapat dilihat pada Lampiran.

Pada tahun ke-1 hasil komoditas mulai menunjukkan net income yang positif sebesar Rp. 1.598.050.000,- namun cash flow menunjukkan nilai negative sebesar Rp.1.299.050.000.- Pada tahun ke-2 hasil komoditas baru mulai menunjukkan cash flow yang positif sebesar Rp. 1.582.806.000,-Sedangkan Cash Flow Cummulative menunjukkan hasil yang positif mulai tahun ke empat sebesar Rp. 1.564.193.520.Sehingga dapat disimpulkan bahwa Modal investasi (Gula semut aren, gula padat aren, madu hutan dan madu kelulut, tusuk sate bambu dan perdagangan karbon) dapat menjadi sumber pendapatan yang baik bagi masyarakat dan KPHP DAS Belayan untuk dapat mandiri.

\section{Kelayakan usaha}

Analisis investasi digunakan untuk mengukur nilai uang atau tingkat pengembalian dari investasi yang ditanamkan dalam suatu usaha pada masa yang akan datang. KPHP DAS Belayan dalam hal ini perlu dilakukan analisa kelayakan usah sebelum kegiatan usaha dengan investasi besar yang sering mempertaruhkan dana yang sangat besar dilaksanakan. Dengan melakukan berbagai macam simulasi tersebut, akan diketahui besarnya faktor-faktor resiko yang akan dihadapi, dan yang mempengaruhi layak atau tidaknya suatu rencana investasi.

\section{Analisis finansial}

Terdapat dua analisis yang sering digunakan dalam penyusunan Bisnis Plan yakni, analisis Keuangan atau finansial (AF) dan analisis ekonomi (AE). E CBA termasuk ke dalam Analisis ekonomi yang diperluas.

Penyajian hasil analisa finansial dan e CBA disajikan dalam format tabel berikut ini: 
Tabel 5. Analisa finansial komoditas KPHP DAS Belayan.

\begin{tabular}{cc}
\hline Kriteria investasi & Analisa finansial \\
\hline NPV & Rp. 9.427 .343 .363 \\
IRR/ERR & $19 \%$ \\
Payback Periode & 7 tahun 3 bulan \\
\hline
\end{tabular}

Sumber: Data diolah,

\section{KESIMPULAN DAN SARAN}

Berdasarkan hasil kelayakan investasi dan analisa sensitivitas maka usaha komoditas (Gula semut aren, gula padat aren, madu hutan dan madu kelulut, tusuk sate bambu dan perdagangan karbon) oleh KPHP DAS Belayan secara finansial layak untuk dibiayai namun dengan tetap memperhatikan hal-hal lain yang belum diperkirakan sebelumnya seperti perubahan kebijakan yang ada.

\section{DAFTAR PUSTAKA}

Chopra, K. 1993. The value of non-timber forest products: an estimating for tropical deciduous forest in india. Econ Bot, 47(3): 252-257.

Dinas Kehutanan Kalimantan Timur (2018) Rencana strategis dinas kehutanan Kalimantan Timur (Renstra), 2018-2023.

GIZ (2017) Penyusunan business plan dalam rangka peningkatan kapasitas manajemen pelaku usaha dan pengelola desa wisata hijau.

Howard, P. 1995. The economic of protected area in uganda: costs, benefits, and policy issues. Unpublished Dissertation, University of Edinburgh, Diringkas dalam Bagri, A., Blockhus, J., Grey, F. dan F. Vorhies (eds). 1998. Economic Value of Protected Area: A Guide for Protected Area Managers. IUCN; Gland.

Ridwansyah, M (2018) Program pembelajaran aksi terpadu panduan penyusunan rencana usaha komoditas/bisnis plan rendah emisi pada kesatuan pengelolaan hutan (KPH) di Kalimantan Timur. GGGI.

RPHJP KPHP DAS Belayan (2018) Rencana pengelolaan hutan jangka panjang (RPHJP), 2018 -2027. 